\title{
The role of global value chains in the impact of the Covid-19 pandemic on the world economy
}

\section{EI Papel de las Cadenas Globales de Valor en el Impacto que la pandemia por Covid- 19 tiene en la economía mundial}

PAREDES-MEDINA, Reyna Myrna $\dagger^{*}$

Universidad Autónoma de Nayarit

ID $1^{\text {st }}$ Author: Reyna Myrna, Paredes-Medina / ORC ID: 0000-0002-6429-6643, Researcher ID Thomson: C-5715-2019, CVU CONACYT ID: 92225

\begin{abstract}
The biggest problem that this health crisis has presented is the strong impact it has had on the world economy. As never before, another phenomenon, the COVID-19 pandemic, has come to put world trade at serious risk. This article aims to expose that. The magnitude of the health crisis is a consequence of the development of the current economic growth model and the role that Global Value Chains, as a fundamental part of the structure of the economic growth model, have had on the impact that this health crisis has had on the worldwide economy.
\end{abstract}

Neoliberalism, Covid-19 pandemic, Global Value Chains

\begin{abstract}
Resumen
El mayor problema que esta crisis sanitaria ha presentado es el fuerte impacto que ha tenido sobre la economía mundial. Como nunca antes otro fenómeno, la pandemia por COVID-19, ha llegado a poner en grave riesgo el comercio mundial. Este artículo pretende, exponer que la magnitud de la crisis sanitaria es consecuencia del desarrollo del modelo de crecimiento económico actual y el papel que las Cadenas Globales de Valor, como parte fundamental de la estructura del modelo de crecimiento económico, han tenido en el impacto que esta crisis sanitaria ha tenido sobre la economía mundial.
\end{abstract}

Neoliberalismo, Pandemia por covid-19, Cadenas Globales de Valor 


\section{Introduction}

The pandemic has exposed the serious problems and deficiencies of the current Neoliberal economic growth model; This model has been characterized as a phase of capitalism of intense competitiveness; Competitiveness has always existed, it is an intrinsic characteristic of capitalism, the peculiarity of this phase of capitalist development is that it is currently a globalized competition, extremely aggressive because it is facing serious disadvantages to developing and underdeveloped economies with large world economic powers; This is because world production was fragmented and offshored 1 throughout the world, organizing itself into long and diverse production chains.

The competition is, therefore, between these chains whose governance is directed by large companies located in developed countries; Another level of equally globalized competition is located at the micro level where the regions and MSMEs of developing and underdeveloped countries compete to be subcontracted by these large companies to form part of the chain, supplying some input of the final product. This mode of production generates a high interdependence between the countries or regions that participate in the chain, therefore, both positive and negative economic effects expand rapidly along the chain, impacting national economies.

In this context of high interdependence, the COVID-19 pandemic upset the fragile balance of the world economy. ECLAC has stated that the impact of the pandemic will cause a crisis of enormous magnitude, even deeper than that of 1946 with a drop in world trade of between $-13 \%$ and up to $-32 \%$ according to estimates by the World Trade Organization (WTO) (Barcena, 2020) and foresees that the recovery could last up to ten years.

\footnotetext{
1 Offshoring is conceived as a process by which productive activities -and not only companies- are concentrated in countries that enjoy greater comparative advantages to exploit them, withdrawing from those others that do not enjoy them, it is a phenomenon Consubstantial with the emergence on the world scene of new large industrial powers, the spread of development to areas until recently marginalized in the wake of economic growth and the international integration of national markets, or economic globalization. Its incidence is radical in labor-intensive productions, in which emerging countries have clear wage advantages to undertake their development. (Myro Sánchez \& others, 2008).
}

vulnerability of this economic interdependence because the economic contraction that occurs in developed economies has a strong impact on the countries that depend on them; and we are talking about a very high percentage of the world's economies. Therefore, it becomes imperative to analyze the impact that COVID-19 has on Global Value Chains because they are the means by which the world economy moves, and internal labor markets depend on the commercial flow they generate, which ultimately they are the ones that energize economies.

Finally, it is appropriate to consider the need for a paradigm shift in the mode of production in which the logic of development is not focused on the commodification of the fundamental aspects of life.

\section{Context of the Covid-19 pandemic}

The COVID-19 pandemic occurs in a period in which the world economy is undergoing a general slowdown, with a low growth rate since the financial crisis of 2008-2009; additionally, the tensions and conflicts between the two strongest economies in the world (China and the US) have generated instability and uncertainty between the commercial zones that depend on them. The deterioration in the growth rates of the world powers and the recurrent crises throughout this century reveal the exhaustion of the current accumulation model. Gambina (2020) states in this regard that "Now we are in the midst of a global crisis of neoliberalism, with the novelty [unlike the crisis of the 70s] that is discussed who hegemonizes the new world order, and therefore the trade war between the US and China "(CLACSO, 2020) among others. The pandemic has only exacerbated what was already occurring, but it has also been the effect of the evolution of the same model. Following this line, the most recent proposals in this regard can be highlighted:

The decentralization process implies the disarticulation of the national scale and the global integration of local spaces, breaking the sectoral unity in the national space, with the aim of increasing the added value at each stage of the product cycle throughout chain. 
Dussel (2020) “... we destroy the conditions for the reproduction of life... the logic of the accumulation system whose rationality is the increase in the rate of profit, where the criterion of the system is money and not life; neoliberalism, privatize everything in an ideal of commercializing it. We have entered a stage of inhumanity "(Dussel, 2020).

Dabat (2020) "1st The pandemic appears at a historical moment in which most of the countries of the world have been suffering from a systematic weakening of the State and public health systems, due to Neoliberalism and privatizations, reduction of public budget and social spending and expansion of private hospitals; $2^{\circ}$ Expansion of the morality of individualism and the weakening of the bonds of social solidarity ". (Dabat, 2020)

Gambina (2020): “... opinions expressed by the IMF regarding the need to expand health spending, diminished by the logic of privatizations promoted by neoliberalism. The absence of beds, respirators, hospital infrastructure and insufficient material for the safety of personnel affected by health, evident now with COVID19, expresses the result of a logic oriented to the market and to public spending favoring a path towards militarization "(CLACSO , 2020; CLACSO, 2020).

Alburqueque (2020): "the origin and spread of the COVID-19 pandemic. The links between the predominant economic growth model and the environmental crisis that in reality the pandemic is part of the effects of this climate crisis, in my opinion [...] where privatization, commodification have destroyed the territorial and national bases of many of the elements of what they call fundamental economics, that is, the set of fundamental activities for daily life), services, industries, infrastructures that are required to ensure health, food, water and energy supply, is say all aspects of the fundamental economy "(Albuquerque, Reflections on the local economic development approach in the face of the COVID-19 pandemic, 2020)

As can be seen, there have been few manifestations of the exhaustion of this accumulation model either.
In the social sphere, the high polarization and social marginalization, together with the greater deterioration of labor security conditions, have led to the emergence of not a few social movements in which the alter-globalists whose motto is "other worlds are possible" can be highlighted ( Pleyers, 2018) in clear opposition to the Neoliberal model imposed worldwide. In the political space, the dispute for hegemony between powers (US-USSR), (US-China) has resulted in major warlike (Vietnam 1955-1975) and commercial confrontations that have destabilized the world economy. In the economic space, the successive crises that have arisen since the beginning of the 21 st century and that have manifested themselves in great and serious problems worldwide, including financial, food, energy, labor and health crises that have impacted world level.

Regarding health crises, it can be said that the repercussions of the neoliberal model have caused radical changes in lifestyles and nutrition, which has led to countries having serious public health problems, among which the World Organization of Health: cardiovascular diseases that represent $12.8 \%$ of deaths worldwide; on weight and obesity that represents $4.7 \%$ of deaths worldwide; diabetes; chronic respiratory diseases; Cancer represents $18 \%$ of deaths worldwide (WHO, 2011) among others, which are attributed to a drastic change in eating habits and sedentary lifestyle.

These figures become important in this context because they already reflect the vulnerability of global health and become comorbidity factors for COVID-19. In summary, the COVID-19 pandemic has not been a fortuitous event, it is an expression of an aggressive and predatory growth model that has generated negative externalities in fundamental areas of life, putting the very existence of humanity at risk in its quest to achieve maximum profits under a mercantile and individualistic logic. What has happened with the COVID-19 pandemic is that it has come to show these phenomena and exacerbate processes that are shaping a reconfiguration of social, economic and political life.

\section{Neoliberal Policies}

How was arrive to this situation? Albuquerque (2020) refers in this regard that: 
This has also been decisively contributed by a type of economic policies that instead of strengthening the fundamental sectors of infrastructure and essential basic services of daily life in each territorial area, have given priority to austerity policies, the cuts in public spending and the privatization of key economic sectors such as health, education, housing, energy, access to drinking water, research and development, public transport or public banking, among other basic services ( Alburquerque, Virtual seminar for the Master's program in Local Development, 2020)

It should be noted that these policies were adopted to give a solution to the crisis of the 1970s and that is what was called Neoliberalism; In the most powerful economies these policies were adopted and promoted, but they were imposed on the less developed economies as a condition for accessing funds from international financial institutions (WB, IMF, IDB) through what was called economic restructuring. in order to access funds from the World Bank. This restructuring basically consisted of a total economic opening, a severe deregulation and privatization of the public sector and a new labor culture was implemented aimed at making the relations between capital and labor more flexible, all this, under a mercantilist logic and an individualistic morality. Thus, the Neoliberal model is installed, with great geographical mobility, especially an impressive mobility of capital, basically due to the weakening of the State and information technologies.

\section{Langard notes that:}

"Flexible accumulation appears as a form of work organization to regenerate mechanisms that allow the recomposing of increasing returns and profit margins, within the framework of more stratified and segmented consumption norms. At the same time, the large transnational companies sought to rebuild their profits from the international fragmentation of those more mature phases of the production process "(Langard, 2014).
The Neoliberal predominance has generated strong changes in economic policy in which the deregulation of economic activity and the privatization and commodification of resources (tangible and intangible) stand out, privileging the market as the optimal form of organization of the economy. The deregulation of economic activity has implied a sharp reduction in public spending in essential sectors to guarantee minimum conditions of welfare and social security.

The dismantling of key sectors for economic and human development, favoring sectors that favor big capital and not only in developing countries but also in those considered to be first world, was evidenced when countries like Italy, Spain, France, United Kingdom, USA, whose health systems were and are being overtaken by the pandemic and register the highest number of deaths from COVID-19. In summary, the enormous inequalities that this model has generated in the world, between and within countries is reflected in the way in which they can cope with the pandemic. Having good health is related to "determinants of health" such as access to education, employment (economy), water and sanitation (WHO).

\section{Impact of the Covid-19 pandemic on global value chains Concept and origin of Global Value Chains}

Gereffi and Korzeniewics (1994) define a GVC as: "a set of networks organized among themselves, grouped around a commodity or product, connecting family units, companies and States within the world economy" (Gereffi and Korzeniewics, 1994) . From this perspective, the chains involve activities of legally independent companies, in a cross-border coordination of cooperation and competition between companies of different sizes in different countries.

The framework for the emergence and development of these GVCs is found in the flexibility of the accumulation of capital consolidated by the process of economic globalization $^{2}$, the adoption of this model implied a strong productive restructuring, as already mentioned above, characterized by the relocation of the productive process.

geographical extension of economic activities, but also the functional integration between internationally dispersed activities (in Gereffi, Humphrey, Kaplinsky, \& Strugeon, 2001).

\footnotetext{
${ }^{2}$ It is worth mentioning that Dikens (1998) points out that the geographical distribution of economic activities across national borders is not a new phenomenon, in fact, it has been a predominant feature of the world economy since the seventeenth century, however, the Globalization not only involves the 
This relocation has been directed by and in favor of the big companies that dominate world trade and production. This productive flexibility has given rise to GVCs, the main motive being the desire to maintain or increase their productivity, the purpose of which is to obtain higher rates of profit; These companies move their production process to regions that offer significant cost advantages, so generally the move is to developing or emerging economies that offer these companies some advantage in their production process; For these economies, the way they are introduced is through agricultural production, basically in the production of commodities ${ }^{3}$ Garammont points out in this regard that:

"This new productive model is concentrated in the most productive agricultural areas and in the most efficient companies, capable of increasing their productivity to counteract the effects of the increase in inputs, while the prices of agricultural products decrease. It is a polarizing model that excludes large or small production units that cannot compete on these terms, fostering concentration of production "(Garammont, 2010).

The concept of Global Value Chain (GVC) arises in this context, expressing the new organizational structure of the capitalist system and a new framework that forces it to face world competition. The main driving forces behind this new productive organization are the investment decisions of multinational companies (MNEs) through their outsourcing and offshoring activities; These are governed by two fundamental factors: the search for a cheap labor force and organizational flexibility, under the logic of cost reduction and risk reduction.

Global Value Chains (GVCs) play a decisive role for developing economies because they represent the means by which these economies with few possibilities of participating in the world market on their own account can do so through outsourcing by large companies. Business; According to the World Bank (WB), GVCs represent almost $50 \%$ of international trade (World Bank, 2020), which means that almost all countries participate in some way in some of these GVCs.

\section{Impact of COVID-19 on Global Value Chains and the implications for Mexico}

In this context, the impact of the COVID-19 pandemic on GVCs is of special relevance since Mexico's foreign trade is strongly linked to them; Agrifood Chains acquire special interest given the economic specialization of Mexico in the links of primary products in labor-intensive GVCs, exporting, through this route, basic or manufactured products. North America is the main trading partner, on which a little over $80 \%$ of Mexican exports depend, with the US being the majority trading partner with $77.85 \%$ of exports. Other important trading partners are Germany and China and not so much because of the percentage of trade that currently exists but because of the potential they represent. Market diversification for Mexican products is a strategy that can undoubtedly boost the economic development of the Mexican regions that participate in them, but above all, provide greater economic stability by not depending to a large extent on a single trading partner.

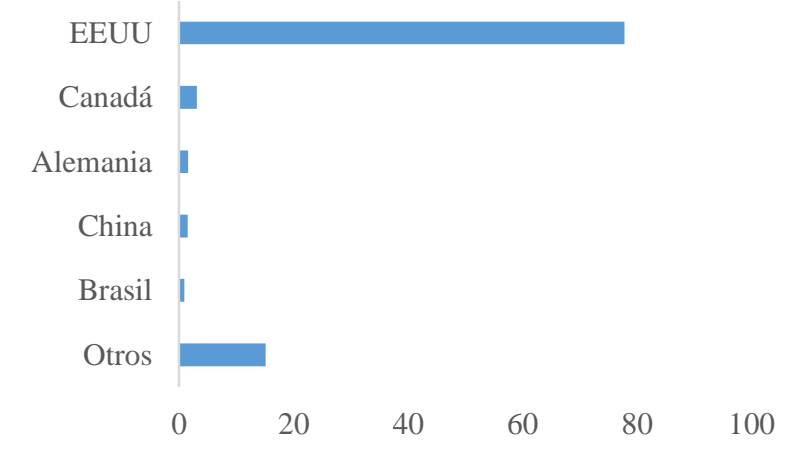

Graphic 1 Percentage distribution of the value of exports of goods from Mexico in 2019, by country of destination Source: (C) Statista 2020

The main concern of the large retail GVCs is the global factory strike; China is the economy that exports the most merchandise to the world and this impacts in two ways: 1) immediately and almost surprisingly, they suffered from a shortage of inputs, or in the best of cases, delays and interruptions in the supply of inputs from China, this hindered and has hindered the flow of the production process in the chain that causes great economic losses due to the stoppage of the process. This interruption is given by the closure of borders that the countries have implemented as a sanitary measure.

\footnotetext{
${ }^{3}$ Commodity is a term that refers to physical goods, without qualitative differentiation, that constitute basic goods of more complex products. (Knight, 2011) 
Especially China and the US, which are huge economies that move international trade. At first, China and the EU close borders and the flow of goods around the world is destabilized since China is the main supplier of raw materials in the world; WTO data indicate that China exports $13.21 \%$ of merchandise to the world and imports $10.80 \%$. These figures give an idea of the strong impact this has on the flow of goods in the world and on the continuity of GVCs. This situation is significant for Mexico, as an importer of Chinese and European goods that represents $1.5 \%$ and $3.5 \%$. respectively, highlighting, in the second case, Germany with $1.5 \%$.

The other way through which it impacts and is more important due to the economic effects that it triggers or deepens in the short and long term is the severe recession that is generated in cascade but especially in these two countries (China and the United States), which are those that move the world economy, the US and China. This recession that is looming not only deep like none in recent decades but also prolonged as it has not been seen in some time. This other factor, an estimated fall in world GDP between $13 \%$ and $32 \%$, according to ECLAC. In the US the contraction is $-3.8 \%$ and in the EU $5.7 \%$ (Barcena, 2020). This economic contraction translates into the worsening of problems that already existed and that countries like Mexico have been dragging since before the COVID-19 pandemic, among the strongest are:

- $\quad$ A high unemployment rate. In both ways due to the slowdown in the economy and the dismantling of some GVCs due to the disarticulation that GVCs are suffering.

- $\quad$ An increase in the poverty and extreme poverty index, especially in the Mexican countryside, which is where a significant number of GVCs are located.

- Food crisis associated with increased poverty and the breakdown of agri-food chains.

For Mexico, the economic contraction that the US presents becomes significant due to the high degree of economic dependence it maintains, as well as the fact that the US ranks second as an exporter of merchandise (8.69\%) and the first to import products from the world (13.34\%) (WTO, 2019).
Therefore, this would be the route that would most impact GVCs because, although it is true that the world market is broader for Mexico, what happens in the US is fundamental.

\section{Conclusions}

However, it seems clear that the Neoliberal model is in decline as a model of economic growth, the health crisis only exacerbated the manifestations of its exhaustion. However, this does not necessarily mean that we are going to transition to another form of productive organization and overcome the Neoliberal order, but rather that it can be resolved with a reconfiguration of it from the reinforcement of the neoliberal foundations, giving partial answers to the problems of this crisis. economic, structural and legitimacy At this point, it seems to me that this dilemma puts at stake the response capacity of civil society in the face of political society and promote a new generation of organic intellectuals to propose and defend new viable alternative proposals; however, the role of the state as a regulating agent of the excesses of the dominant elite that organizes the dynamics of capitalist accumulation must be seriously rethought.

The Global Value Chains play a fundamental role in the development of world trade since they are the structure that gives road and support to the flexibility of the capital accumulation model, but their importance is also based on the fact that they have been the vehicle for economies less developed can link to the world. This has been an opportunity to energize these economies, the cost has been high in most cases but it has also allowed the transfer of technologies and the training of human capital through know-how in specific areas.

From this perspective, it is necessary to rethink the type of commercial policies that allow the looting and depredation of resources that until now has meant the model of flexible production and formulate policies that are sustainable and that allow to take advantage of and capitalize on the opportunity represented by the transfer technology and human capital formation from GVCs in developing economies. 


\section{Opportunities for Mexico from the GVCs}

The imminent danger of a permanent breakdown of some GVC registers the opportunity to develop regional linkage strategies that respond to the demand of the chains to re-establish the continuity of production and commercialization flows and that allow strengthening the national economy.

Mexico can take advantage of the situation of this crisis to promote endogenous development by strengthening the internal market by generating networks of suppliers of the inputs that have been imported until now; The know-how that the companies linked to the large global chains have acquired will allow the creation of spin off for the supply of the necessary inputs in the elaboration of the final or intermediate products of the national links and of the same GVCs, even scaling in the structure of the chain in order to retain greater added value.

This would lead to the consolidation of regional economies by linking national links with the configuration of networks of new national providers, linking regions and localities and ceasing to be just disjointed enclaves that are not capable of dragging the national and regional economy to levels of higher development.

This is not an easy task, especially since in Mexico there is a huge disengagement of the companies subcontracted by the large companies that run the chain and the regional and national economy. Therefore, an institutional network is required to provide support in the areas that most require this link and the most important are financial institutions because the links found in the national territory face serious financing problems that are generally solved with direct foreign investment of the same companies that hire them. In this sense, the State must play a leading role, especially in this recession in which significant economic financing is required to be able to reactivate the regional, national and world economy; in that order; In other words, take a turn to strengthen and diversify the national offer and not depend so much on the international market, this will allow to strengthen the regional economy.

\section{References}

Alburquerque, F. (27 de noviembre de 2020). Reflexiones sobre el enfoque de desarrollo económico local frente a la pandemia de COVID-19. Seminario de la MDEL . Tepic, Nayarit, México.

Alburquerque, F. (19 de noviembre de 2020). Seminario virtual para el programa de Maestria en Desarrollo Local. Reflexiones sobre los origenes del covid-19 . Tepic, Nayarit, México: UAN-MDEL.

Banco Mundial. (2020). Informe sobre desarrollo mundial 2020: El comercio al servicio del desarrollo en la era de las cadenas de valor mundiales. Banco Internacional de Reconstrucción y Fomento/Banco Mundial. Washinton, DC: Banco Mundial.

Banco Mundial. (2008). Incentivar la innovación agrícola. Como ir más allá del fortalecimiento de los sistemas de investigación. Bogotá, Colombia: Mayol ediciones S.A.

Barcena, A. (2020). $2^{\circ}$ Informe especial COVID19, CEPAL. CEPAL. Santiago de Chile: CEPAL.

CLACSO. (2020). La pandemia COVID-19 agrava la crisis capitalista. (CLACSO, Productor) Recuperado el 28 de diciembre de 28, de Pensar la pandemia: observatorio social del coronavirus: https://www.clacso.org/lapandemia-covid-19-agrava-la-crisis-capitalista/ Langard, F. (30 de junio de 2014). Consolidación de cadenas globales de valor y desarrollo de clusters locales: el caso de la maquinaria agrícola en Argentina. Tesis Doctoral . La Plata, Argentina, Argentina: Universidad nacional de la Plata.

Dabat, A. (7 de mayo de 2020). Reordenamiento Global y Pandemia por COVID-19. Programa Globalización, Conocimiento y Desarrollo. (C. y. Programa Globalización, Entrevistador)

Dussel, E. (9 de abril de 2020). Pensando al Mundo: COVID-19. Pensando al Mundo: COVID-19. (t. sur, Entrevistador)

Garammont, H. C. (2010). La Evolución de la Producción Agropecuaria en el Campo Méxicano: Concentración Productiva, Pobreza y Pluriactividad. Andamios , 7 (13), 85-117. 
Kaplinsky, R. (1999). Spreading the gains from globalisation: What can be learned from value chain analysis? IDS working paper, 110, 1-37.

Myro Sánchez ， R., \& otros. (2008). Globalización y deslocalización Importancia y efectos para la industria española. Madrid, España, España: Centro de publicaciones del Ministerio de Industria, Turismo y Comercio.

OMC. (2019). Estadísticas: Perfiles Comerciales. Recuperado el 26 de diciembre de 2020, de Pefiles Comerciales: https://www.wto.org/english/res_e/statis_e/dail y_update_e/trade_profiles/CN_s.pdf

OMS. (2011). Informe sobre la situación mundial de las enfermedades no trasmisibles 2010. OMS. Ginebra, Suiza: Organización mundial de la salud.

Pleyers, G. (2018). Colección: Democrácias en Movimiento. (CLACSO, Ed.) Buenos Aires, Argentina, Argentina: CLACSO.

Sztulwark, S. (27 de noviembre de 2020). Los efectos socio-económicos de la pandemía en América Latina. Seminario del PROGLOCODE . Ciudad de México, Ciudad de México, México: IIEc. 